\title{
Previous to Present Policies and Approaches for Slum and their Limitations: In Search of Sustainable Slum Upgrading Process in Developing Countries
}

\author{
Kashfia Alam Khan \\ Department of Architecture, Primeasia University, Dhaka, Bangladesh
}

\begin{abstract}
Slums- the living areas of urban poor, have always been treated like a burden for the city. But in reality, the labor of the slum dwellers is running the city mechanism. In developing cities it has become obvious to think about the slums in urban planning strategies as it is an unavoidable part of the city. Slum upgrading has been a complicated issue for decades in poverty surrounded countries of the world. Despite many experiments have been done till now, none of the process is proven to be sustainable to be used as a model for the poverty surrounded slums for upgrading. In this study the main idea was regarding the rationalization of slum upgrading models which are tend to be used as prototypes. The argument about sustainability of top-down program based slum upgrading projects is still very ambiguous in case of developing cities. Failure of top-down projects has promoted urban designers and urban planners to think about alternative approaches. In this research the aim was to find out the key reasons that are responsible for the unsustainability of the approaches of slum upgrading in developing world. At the end of the study modern complex theories of city life are interpret to point out that the intangible elements of slums are the essential part to consider for any upgrading system.
\end{abstract}

Keywords: Urban poor, slum, slum upgrading, urban design

\section{INTRODUCTION}

$\mathrm{E}$ conomic and social disparity is quite apparent in third world developing countries such as in Bangladesh, India, Philippines, Africa and even in South America. Cities of developing world are expanding and more people are coming from the villages to the city for getting higher wage or just for survival. But they cannot afford to live in the city. Consequently slum builds up in some areas inside the city organically. As developments increases in the city, slums build up side by side simultaneously.

People who live in the slums are basically the manpower who works for low-income jobs, mainly labor work in the city. The income difference is huge between the rich and poor in developing cities and at this world of competition, the difference is getting bigger and bigger. Rich people are getting richer and poor are becoming poorer. This unexpected truth has been forcing the urban poor towards extreme poverty which has created a significant difference in urban rich and urban poor. At the end, the slums become very segregated individual parts of the city. city people remain totally away from the slum areas, consequently, slums are thought to be a burden for the image of a formal city.

There were many slum policies taken over many years like eviction, neglecting slum people from urban services, relocation or resettlement etc. But eventually cities have now understood the importance of the slum people for their large contribution for driving the city economy and city mechanism. It is actually difficult or even impossible to make slums totally disappear from the city in a humanistic way until or unless they are fully supported financially which is difficult for an underdeveloped city. Finally 'slum upgrading' has taken the place of 'eviction' in many cities around the world so that the slums can co-exist in the city but in an 'upgraded version'. But none of the approaches could be able to become a concrete model for eliminating slum problems in developing countries. Most of the slum-upgrading projects become unsustainable or it is difficult to uphold the objectives after some years of implementation.

This paper presents different kind of slum policies and approaches that have been taken worldwide from past to present and the underlying cause of slum upgrading processes not being sustainable after several years; and at the end, presenting modern complex system theories of city to rethink about the slum-upgrading policies. The purpose of this study is to find out reasons behind complexities of slum upgrading in developing countries. The main idea was to unite human behavior with the physical environments, i.e. integrating intangible elements of urban design, such as resilience, selforganization and complex networks, with the physical or tangible elements, such as built forms, infrastructures and facilities, for the sustainability in slum upgrading processes.

\subsection{Scope of the study}

The study will further open a ground for research on sustainable program based slum upgrading projects for individual slums in developing world, as it have been a complicated and ambiguous for decades.

The study also introduces the argument for rethinking the definition of slums and categorization of slums in the prospect of international organizations for better understanding its characters and addressing their problems in the right track. 


\subsection{Selection of approach}

The approach for the study was mainly revising the literatures, which directs to a qualitative analysis of slum upgrading concepts.

The main idea is to analyze the relationship of 'physical elements' or 'tangible elements' with the 'intangible elements' of the society. The tangible elements represent the built forms of slum upgrading i.e. infrastructures, facilities, etc; and the intangible elements represent the human behaviors through analysis of different systems defined by the scientists and philosophers in social and economic sectors. Based on this parameter, the case studies of different slum policies from past to present applied around the world, are represented in this paper to rationalize them with the modern complex system theories.

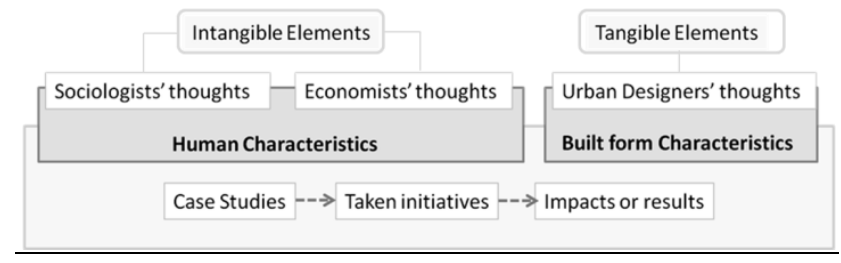

Fig 1. Basic methodology of the study

\section{PREVIOUS TO PRESENT: POLICIES AND APPROACHES FOR SLUM AND THEIR LIMITATIONS}

\subsection{Self-help housing (1950-1960s)}

From history we can see that after industrialization of the cities, huge number of people moved to the cities leaving declined agriculture based village life. Shanty ${ }^{1}$ type housing had given a quick and easy solution to the urban immigrants at that time, as it is cheap, quickly and confirms economic mobility. Since the inhabitants of the shanty towns are directly involved in the housing process, shanty towns can be regarded as the first introduction to self-help process of housing. As this autonomous procedure was made of temporary materials and was not claiming any aid from the city authorities but provided service to the city, it was initially thought to be the support for well being and welfare for the urban poor [8]. But eventually these self-help shanty towns became uncontrolled and expanded later on with poor hygiene and poor living condition which is known as slum today.

\footnotetext{
${ }^{1}$ A shanty town or squatter area is a settlement of improvised building that is known as shanties or shacks, made of plywood, corrugated metal, sheets of plastic, or cardboard boxes. This is sometimes called as a squatter, or spontaneous settlement [21]
}

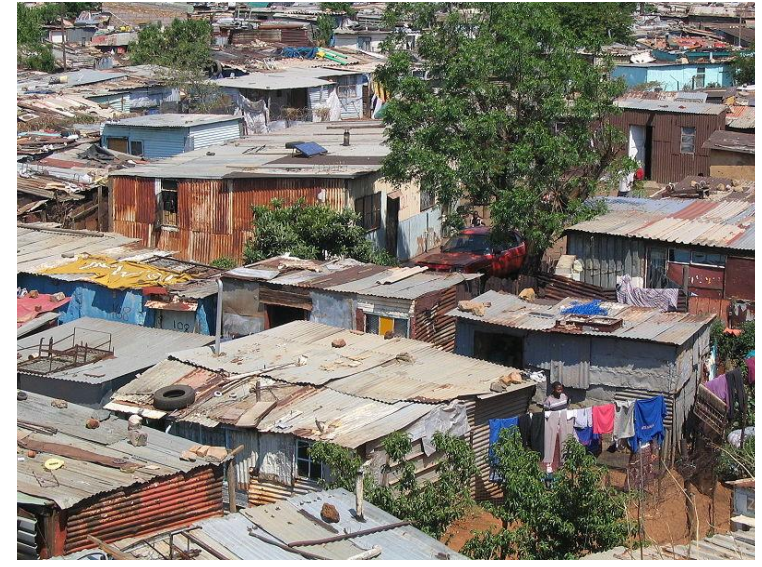

Fig 2. Shanty town in Soweto, South Africa, 2005 [21]

\subsection{Eviction}

Eviction is the clearance or demolishing of the slum with a prior notice. Previously in developed countries urban poor settlements were usually moved out or cleared from their place for urban redevelopment. Critics argue that slum removal by force tend to ignore the social problems that cause slums [9]. It may remove the slum, but it does not remove the causes that create and maintain the slum. Experiences show that after effects of slum removal or eviction have always been negative. As the slum is connected with the city in terms of economy, wage and livelihood, the slum dwellers tend to find out another place to live in the same city but elsewhere. And that is obviously more shanty type and worse than the previous one. In developing countries the practice of eviction is still very common as they think the slums are illegal, so no compromise to them.

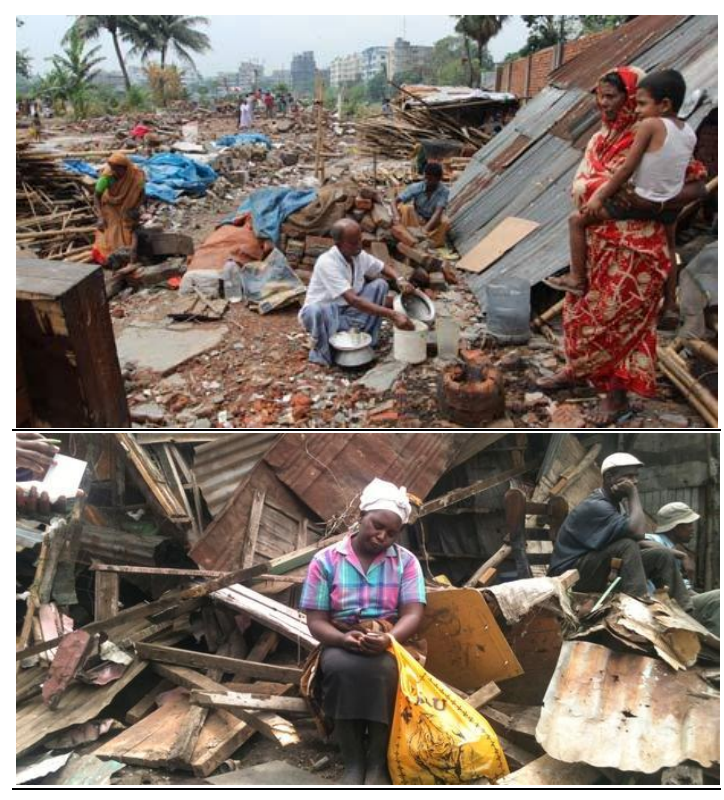

Fig 2. (above) eviction in Karail, Dhaka, 2012

(below) eviction in a slum in Kenya, Nairobi 


\subsection{Benign neglect}

It is a different approach of slum policy that were applied in some developing countries between 60's and 70's, where the slums were expected to be cleared automatically by Ignoring slums by providing 'no service' such as legal authenticity or any public service. By saying a 'benign' the policy makers thought the 'market' will take care of it, as the urban poor settlements are the temporary solution for the immigrated people who are willing to be shifted to formal housing later on [9]. However, it became clear that this approach has no outcome of controlling the expansion of slum in urban area.

\subsection{Slum relocation/ resettlement}

It is a policy to remove the slum from its location to another place for the sake of redevelopment in that urban area and to get a better urban environment. This is a common practice in developed countries where the governments have the ability to develop adequate public housing for the low-income people and replace them with new job opportunity. But the situation is different in developing countries, where resettlement of the urban poor to another area takes away the slum dwellers far away from their working place which causes more expense for travelling and consequently creates joblessness, because city is the only place where the urban poor can earn. Although, the relocation and resettlement is done for the betterment of the living standard of the slum people with government aid, it does create new problems of joblessness and new poverty resulting re-immigration of the people in the city. In Egypt, there are several examples of slum relocation happened, replacing thousands of slum dwellers from the city to outside, which resulted huge number of people becoming jobless [7].

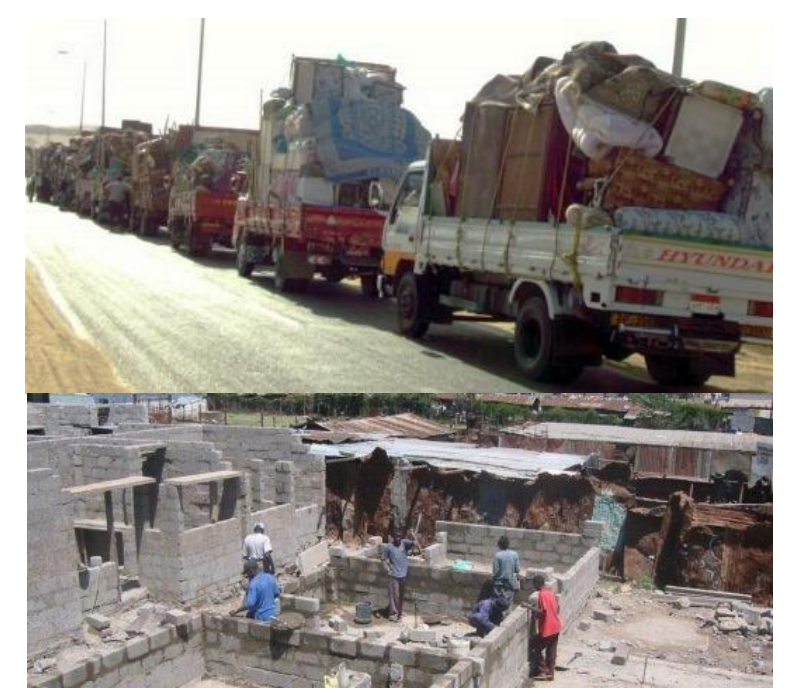

Fig 3. (above): Trucks transport the furniture of residents of Istable Antar slum in Cairo to new homes about $50 \mathrm{~km}$ outside the capital;

(below):Self-help housing program in Kambi Moto community, Kenya. Image source: [7]

\subsection{Slum Upgrading}

By the 1970s it became clear that none of the slum policies were adaptive or effective to address the root cause for the expansion of the slum in developing cities. As long as it was clear that the slum dwellers are contributing to the core economy of the city, a new concept of dealing with the urban poor settlements emerged, thinking that urban poor can find their creative solutions to improve their livelihoods if they are facilitated with basic infrastructure, improved sanitary conditions and improved environment by the local government. Upon completion of these basic improvements, slum dwellers will invest on their own dwellings inspired by the improved living standard. This aided self-help paradigm was inspired by earlier experiences in Europe and influential work of British architect John F.C. Turner, who was also the pioneer to introduce the 'land-tenure' approach for slum upgrading policy [9].

Turner's theory suggests that, as the environment improves, most slum residents will gradually better their homes and living conditions, especially when encouraged by security of tenure and access to credit [16]. While land tenure was recognized as important, it was not seen as an essential precondition for a successful slum upgrading project. The role of government, according to Turner, is a minimal one, simply to expand human aspirations.

\subsection{Mutual / organized Self-help housing}

Self help housing is a concept of slum upgrading that saves money for both for participant and funding sources because the labor cost is free. Self-help housing program often offers land-tenure, partial funding, construction materials or certain types of benefits to the inhabitants in a condition that they will give a minimum hour of direct labor to built their own house. A good example of self-help housing program is presently running by USDA in their Rural Development Housing and Community Facilities Programs, although it is not actually for a slum upgrading, which offers a 'mutual self-help' housing loan which targets to help very low-income households to construct their own home under qualified supervision [19].

\section{PRESENT APPROACHES OF SLUM UPGRADING AND SOME RECENT EXAMPLES}

Presently slum upgrading is the most popular approach to the urban planners or architects to deal with the slums in the city. There are two ways of upgrading a slum, one is Top-down as it is led and started by the government or funding source, and the other one is bottom-up as it is started by the participation of slum people [3].

The top-down approach is basically a 'program' based process to address the slum problem from the funding authorities or government by a preplanned physical design. Because of the complexities related to economy, politics and other poverty related aspects in developing cities, top-down upgrading programs cannot be always implemented very efficiently. 
Even if the better housing or better living facilities are provided to the urban poor with a successful implementation, experiences show that the slum dwellers tend to ignore proper maintenance of the common service areas as it add an extra cost and time to their daily life. As a result top-down approaches often become chaotic.

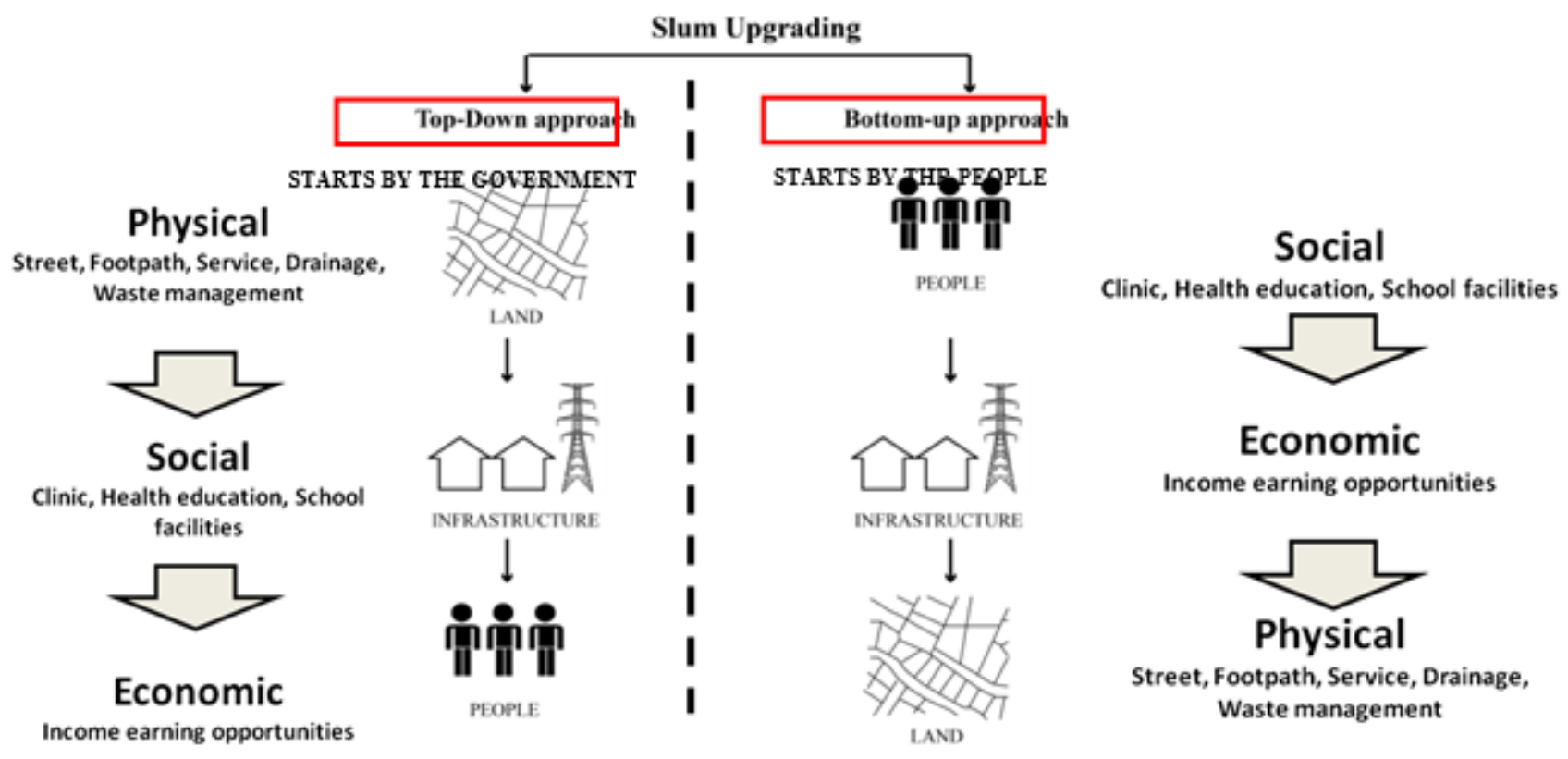

Fig 4. Difference between 'Top-down' and 'Bottom-up' processes

Bottom-up approach, on the other hand, thought to be a solution over top-down approach and the developments are expected to be maintained by the dwellers as it gives the residents a sense of belonging as it is led by the people, started by the people through spontaneous participation of the people of the slum to build their own house and planning the slum for better environment.

Top-down project aids usually takes a long time and goes through many hands before it reaches the people who need. And when it is a big scale project, the budget gets higher and as well the corruption, and finally while distributing, per head aid becomes almost negligible. It is much better to start the community savings from the people. When people save together, they become aware, more responsible and conscious; they manage their own money and get organized

\subsection{Slum Upgrading program by UN-Habitat: Participatory slum upgrading Program (PSUP)}

In 2008 the 'Participatory Slum Upgrading Program' or PSUP was launched, which targets to improve the living conditions in towns and cities and positively contribute the millennium development Goal $7^{2}$, Target $11^{3}$, to improve the lives of at

\footnotetext{
${ }^{2}$ Goal 7: 'Ensure environmental sustainability'

${ }^{3}$ Target 11 : 'Have achieved by 2020 a significant improvement in the lives of at least 100 million slum dwellers' Error! Reference source not found.
}

least 100 million slum dwellers by the year 2020. The program is initiated by $\mathrm{ACP}^{4}$ Secretariat, funded by European Commission and implementing now by UN-Habitat [18].

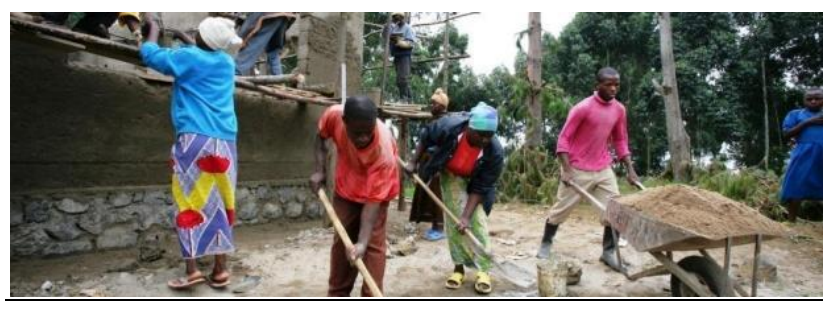

Fig 5. PUSP in Kenya by UN-Habitat 2008(UN-Habitat, 2014)

In an overview documentary video of PSUP program a team leader Semiti Qalowasa, from the 'People's Community Network' in Fiji slum upgrading program says, "one of the main problem of the slum people is the insecurity of the land tenure. The houses in the squatter settlements are all temporary, because they do not know when their houses will be evicted." [10].

It is now believed that slum people can build their own houses and maintain it with care if they can get a sense of belongingness. Slum dwellers do not invest for a permanent or good structure because they always have a fear of eviction. From this concept, giving'secure land tenure' to the slum

${ }^{4}$ ACP stands for African, Caribbean, and Pacific Group of States 
dwellers for the scope of building their own house by themselves is thought to be the ultimate leading strategy for slum upgrading today.

\subsection{Street led city wide slum upgrading concept}

This is another new slum upgrading concept recently proposed and being researched by UN Habitat for slum upgrading where streets are regenerated to play the role of income generation and social interaction which can definitely help revitalization of a deadly society. As the conventional slum upgrading methods are not working or solving the booming expansion of slums around the world, Claudio Acioly (2014) in his UN Habitat Lecture Series argues that 'we need a different strategy to address the global problem'. The proposal is a twin track approach which promotes that the slums should be upgraded with a single city wide program under which the urban housing strategies are also implemented.

"Streets are not only a physical entity of mobility and accessibility, Not only the pathway for sewerage and pipes, power lines and drainage system, it is a common good and the public domain -the public space- where social, cultural and economic activities are articulated, reinforced and facilitated." [1].
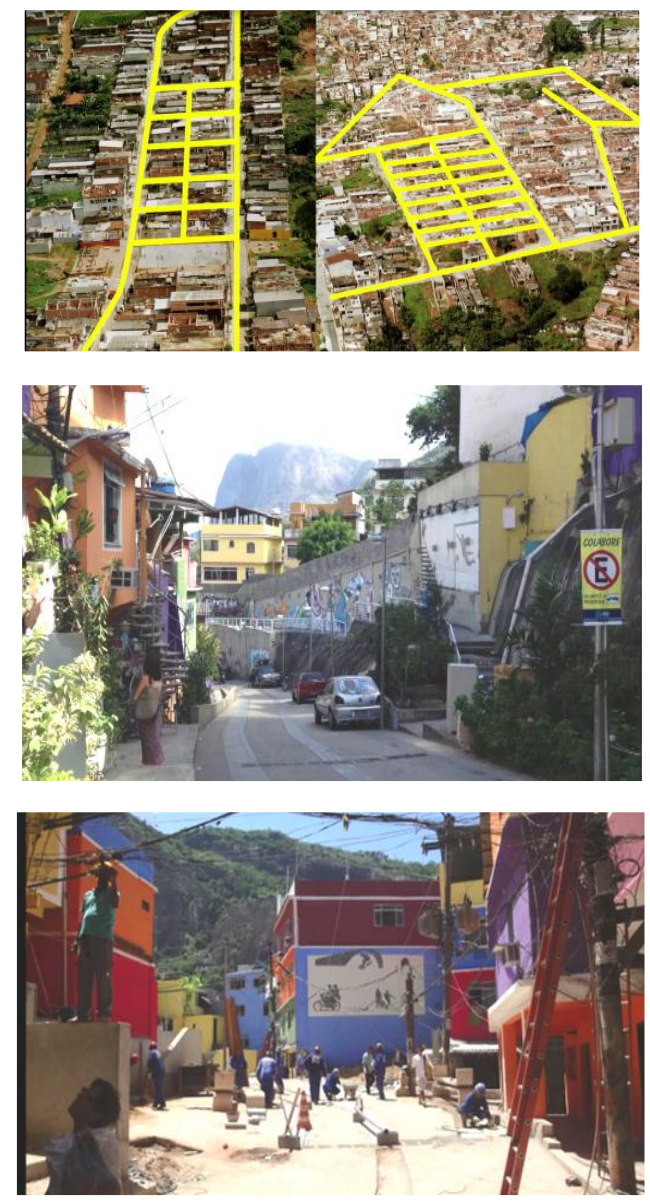

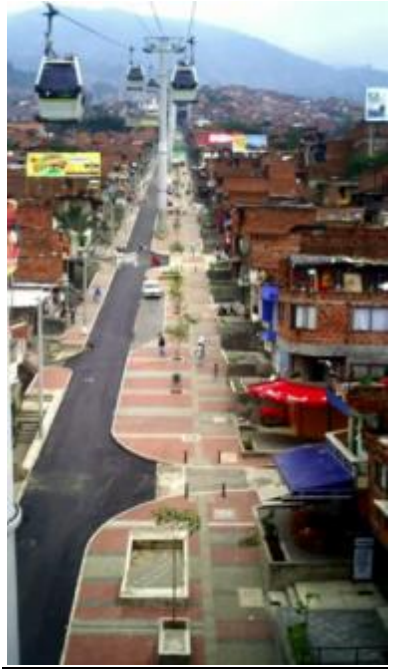

Fig 6. Street led city wide slum upgrading. Source: [1]

For no doubt, this is a program based top-down approach, which again brings a question mark for the idea of 'imposed' implementation of a project to an unknown neighborhood which may not be successful at the end, as it can hardly enter the core problems of individuals.

\subsection{Supporting tools for Bottom-up approach of slum upgrading}

The bottom-up approach is not only initiated by the people, it is also directed by the people. But for designing, drawing and construction technique there are supporting tools from the UN Habitat, known as GLTN (Global Land Tool Network), which was started about 5 years ago [3]. In these tools UN Habitat gave much importance for securing land and property rights for the slum people, so that they can achieve security tenure from the government through strong argument with proper data and design. The level of governance and the operational and strategic role are played by the slum dwellers themselves. The involvement of the stakeholders only happens during project process and access/use of the project [15].

There are some social organizational institutions also, like ACHR 5 who are working for the community development among the urban poor for making savings group and support each other in a combined action through the program ACCA (Asian Coalition for Community Actions). ACCA gives support to link scattered communities through a financial network. $\mathrm{CODI}^{6}$ is another institute working for Thailand under the program Baan Mankong city wide slum upgrading in Thailand.

A successful implementation of bottom-up approach by giving 'land tenure' is being implemented in Thailand, for the Baan

\footnotetext{
${ }^{5}$ Asian Coalition for Housing Rights

${ }^{6}$ Community Organizations Development Institute
} 
Mankong $^{7}$ community upgrading program. The program had set a target for upgrading the housing and living environment for 300,000 families in 2,000 poor communities in the city within four years from 2005-2008, getting positive results from the first10 pilot upgrading projects that had been being implemented from 2003. The main idea of upgrading the slums in Thailand is giving a secure tenure to the slum dwellers so that they are more interested to invest in their own houses and surroundings. But it has to be controlled, directed and managed by a professional team so that the whole process become 'organized'. The whole process is known as 'Organized self-help'. According to CODI these upgrading projects improved $87 \%$ of households giving tenure security, either by purchasing their former land or negotiating some kind of collective lease [5][6].

According to CODI (2005), " It turns out that it is not really such a problem after all for all urban poor communities to stay in the city where they have been, with better status and social physical improvement."

\subsection{Evaluations and limitations of recent slum upgrading projects}

It is very important to evaluate the projects of slum upgrading to avoid errors in future implementations. As slum upgrading is a continuous long term process it is difficult to evaluate current projects, but we can get some ideas from similar approaches that are implemented on previous decades in developing cities.

World Bank's largest slum upgrading effort were started during 1980s, based on Turner's theories, particularly by his book 'Freedom to Build' [16][20]. Based on Turner's idea World Bank started funding for slum upgrading programs to alleviate the poverty problem by upgrading slums in Kolkata (Calcutta, India), Jakarta (Indonesia) and Manila (Philippines) by the earl 1980s. According to Hebert Werlin, who had worked for World Bank Urban Projects Department from 1977 to 1983 , the early evaluation of the projects came with positive results and validated Turner's theory in a way, as the overall environment of the slums had improved by the program. But the later evaluations after 5-10 years of each project applied, shows ephemeral results which brought the whole project under the question of its validity or sustainability [20]. However, in World Bank's earlier attempts of slum upgrading, the concept of giving 'landtenure' (according to Turner's theory) was not given priority at that time.

The recent approaches, either it is top-down or people driven, are generally applying the same tool 'land tenure' (according to Turner's theory) to all slums as a 'prototype', thinking that the slum dwellers actually do not built or repair their houses for the lack of tenure security, because they do not know

\footnotetext{
${ }^{7}$ Baan Mankong- "Secure housing" in Thai.
}

when they will be evicted [16]. It is thought that creating a 'sense of belonging' through physical design will work for urban squatters [14]. This conventional belief of land tenure is getting so generic that it is not even considered if the slum dwellers whether or not can afford the house cost. As the present approaches of slum upgrading are still under experiment, we can hardly evaluate them for sustainability issues. But the base of assessment can be predetermined for the sustainability issues. There are similarities in the present process and previous processes. The present approach is more people oriented ensuring more community participation so that the slum dwellers actively upgrade their own area. But there is still a major importance for the security of tenure which is thought to be the main push factor for the poor to upgrade their living spaces by themselves.

However, complexities are everywhere in developing cities from the grass root slum dwellers to local government while slum upgrading. Giving 'land tenure' and organizing the community is not always very easy to deal with. The ownerships of slum lands often seems very complex to handle. Seldom the residents own both their house and ownership of the land. While many residents may simply be occupying vacant lands, but negotiated with the original land owner and paying monthly rents to them. Sub-letting arrangements can also be seen in many settlements. Despite of being unauthorized, the slum lands are seldom seen to be legally or illegally owned by group of people who may not live in the same slum but they sub-let the land to several households, so there are many problems related to undertaking the land registration [20].

The concept of participatory 'self-help housing' also often found difficult to be successfully implemented. Specially when it is implemented in large scale projects. According to R.J. Martin, project components and standards may not accord with the residents' priorities, as well as the total financial consequences of the project may not accord with residents' wishes or ability to pay [12].

Even though there are some advantages of large scale projects such as the cost of material is counted in bulk for large number of similar houses, high costs for administrative arrangements as well as training purpose for the inexperienced slum dwellers become troublesome to handle during the implementation period [2]. Large projects are also expensive in the long run as maintenance costs continually get higher immediately after resettlement of the dwellers, as the materials used are cheap and non-durable and also the slum dwellers tend to neglect the responsibility to maintain the surrounding environment. Vandalisms, negligence to maintenance, poor quality low cost materials, political corruption over funding a lot more complicacies are related to the large scale slums in developing cities.

Although, present approaches of slum upgrading are more focused on conventional idea of making a 'better environment', it is difficult to build the 'sense of necessity' for 
achieving a 'nice environment' in the poverty oriented slum people. Because the taste of the slum dwellers are not as 'urban' as the middle income or upper class city dwellers [2]. The slum people are more rural than urban in cities like in Kenya, India or Bangladesh. As long as the sense of 'nice environment' is not present in their priority list of problems, the maintenance of the upgraded slum is a challenge for its sustainability.

Slums around the world are basically different from each other based on the life style or living status of its people. If we categorize the slums according to its physical elements, it is very difficult to classify them as the scale of the slums or the typology of settlements are very much different from each other despite of having the same problem in the cities. But if we categorize them according to their living standard to address the basic problems of a slum, all the slums can be classified into this graph:

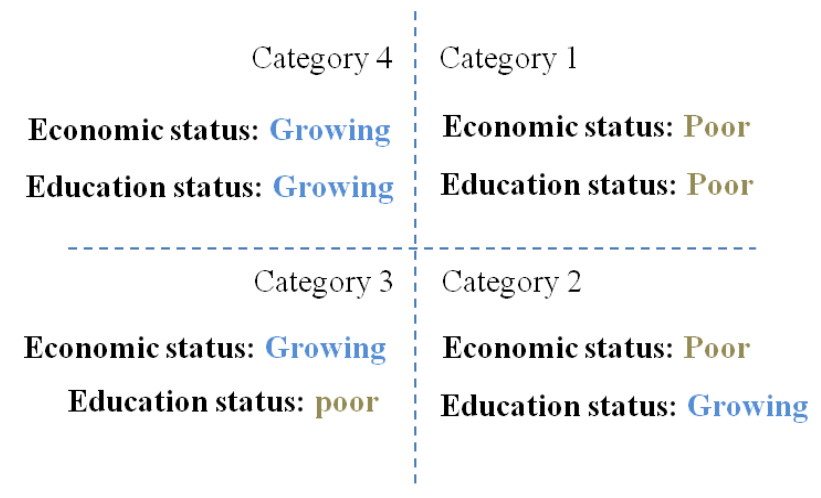

Fig 11. Slum categorization based on living status.

In this graph the tangible elements are ignored, but intangible elements are given priority. The living standard of a slum actually depends on and responses to the intangible elements such as education and economic growth. Merely upgrading of physical elements cannot make an upgrading program sustainable unless we think about the intangible elements develop along with it to uphold the result. Because economy and education are such things which uplift people's selfesteem and creates a spontaneous bottom-up effort in the slum dwellers mindset, which is very important to uphold the sustainability of a slum upgrading process.

In poverty surrounded slums, that are in Category 1, with declined education and declined economy, both top-down and bottom- up processes of slum upgrading are susceptible to be unsuccessful in the long run. The top-down approaches most often collapse either it is participatory or non-participatory, due to lack of maintenance, investment, repair cost, low cost materials, vandalism, over population for new migration, and above all poverty. On the other hand, bottom-up approaches also may become unsustainable in Category 1 slums if there is a lack of 'push factor' (like education or inspiration) which could help them realize the importance of upgrading of their living standard.
The sustainability of the slum upgrading basically depends on two aspects:

01. Stability of the improved situation of slums

02. Influential multiplication of the upgrading process throughout the slum community for successful piecemeal progress.

Based on that, the following flow-charts are made for a better understanding of the process of slum upgrading:

Non-participatory Top-down approach:

Expected:

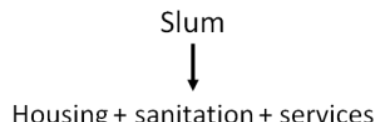

Housing + sanitation + services

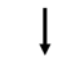

Relocation

Living and maintenance (Cost come from monthly rents)

Upgraded slum

\section{Reality:}

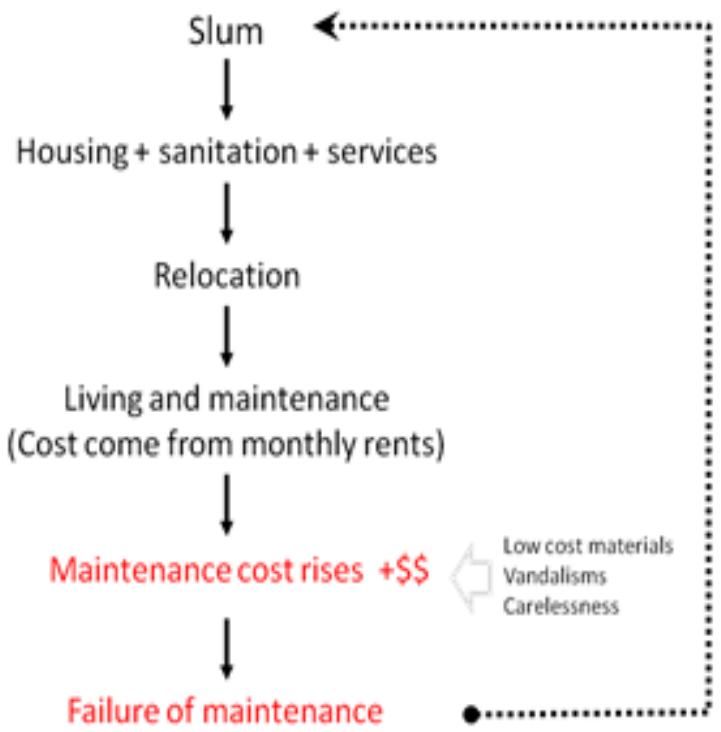

Fig 3.44: Participatory top-down approach process

Participatory Top-down approach:

Expected: 


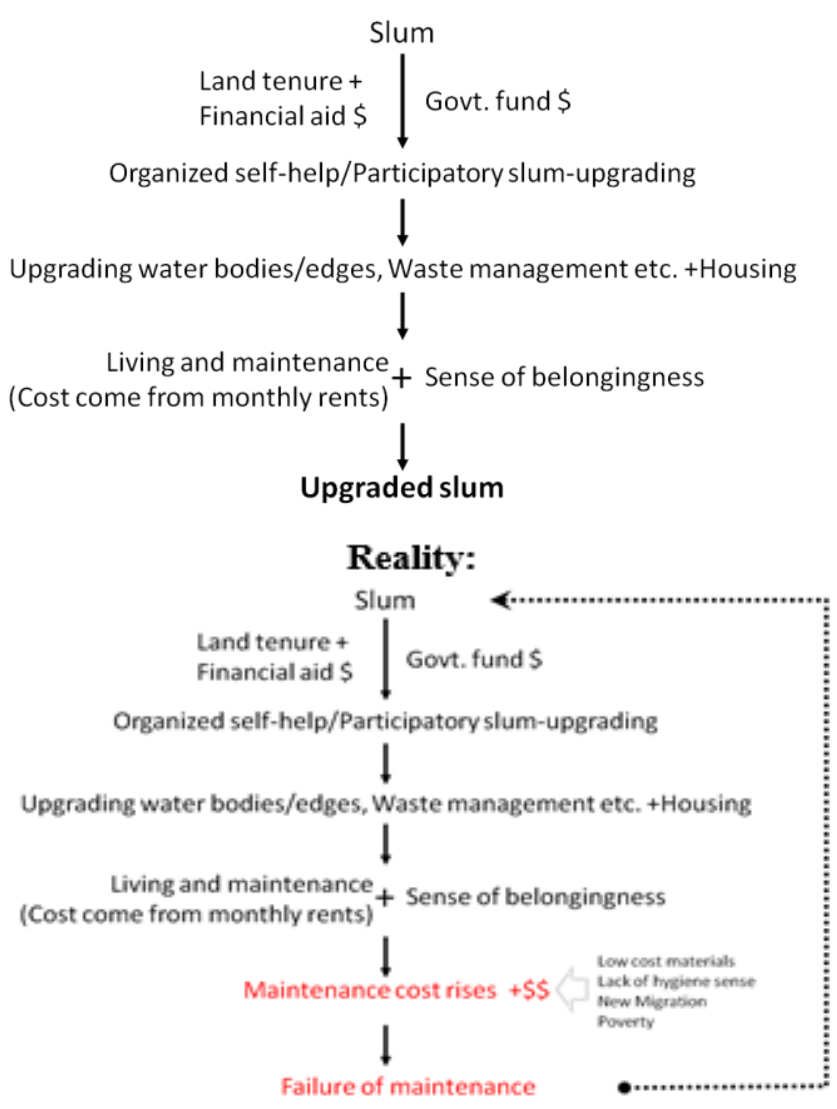

Fig 3.44: Participatory top-down approach process

On the other hand, bottom-up approaches are seen comparatively sustainable in Category 1 slums. As the implementation here is a continuous process. But still they need a 'push-up' factor to grow the status of their economy and education to understand the importance of upholding the upgraded living standard.

\section{Bottom-up approach:}

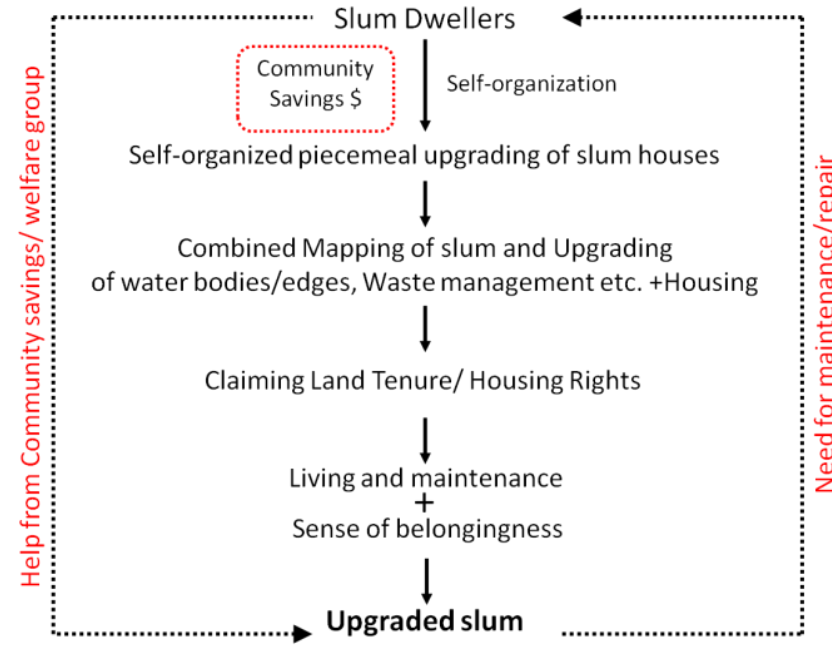

Fig 3.45: Bottom-up/ people driven approach process

\section{CONSIDERING MODERN COMPLEX THEORIES TO COMBINE TANGIBLE AND INTANGIBLE ELEMENTS OF SLUM TO UPGRADE TOGETHER:}

\subsection{Considering the city as a whole: 'The Web of life'}

Although slums are occupied by the people who come from outside of the city, a slum is strongly related with the city system economically and physically. Generally as the slum people want to live and work inside the city, slums are situated nearby the central places of a city organism.

Every system has its own networks. just like that, the city has its own networks where the main physical elements are its people and infrastructures. These elements can make small groups of work zones which are interconnected and interdependent to each other for business, collaboration and organization. Just like a living organism, a city circulates its population for the work processes and every physical part of it plays the role of its organs.

According to Fritjof Capra (1996), living organisms are best understood as integrated whole rather than part by part. -"there are no parts at all. What we call a part is merely a pattern in an inseparable web of relationships." and "...The world is an integrated whole rather than a dissociated collection of parts" [4]. Such like that, a city can only be understood if we see it as a whole, rather than breaking it into parts, as we do it today, by calling the living areas of a selective group of people as 'slum' -making it as a segregated part of a city. We can never solve the problem of slums if we do not think of the whole city mechanism together; considering economy, industry, merchandize, institutions, housing, society, culture and all other parts, along with the hawkers, rickshaw pullers, cleaners, genitors, house-keepers and other low-income groups of people, who are helping to run the city, who are responsible for the formation of slums.

If we compare a city with a healthy living body, and after several years undersigned unplanned slums are seen in the healthy urban area as an uncontrollable establishment, we often interpret them as an unwanted situation in the city, and try to solve them with new policies. We can compare the slum with a break out of 'cancer cell' in a healthy body of the city, when slums are uncontrollable and fast spreading like cancers and it creates disturbance to the designed spaces (creating social and physical crimes/ illegal occupancy etc). But it is, actually a natural phenomenon of an outbreak of population of the city for immigration and class difference. It is not only done by the urban poor but also done by the middle income and rich for the reason of business, employment and investment, and most importantly, for the mistake of the city planner for not considering the immigrants while planning the program of a city. Migration and overwhelming rise in population is simply one of the basic characters of a developing city.

In a living organism when there is a disease in its body part, we never eradicate it; rather we prompt to take medicines to 
cure the disease. But if we only focus on curing the disease not concerning the whole system together, it may give a bad

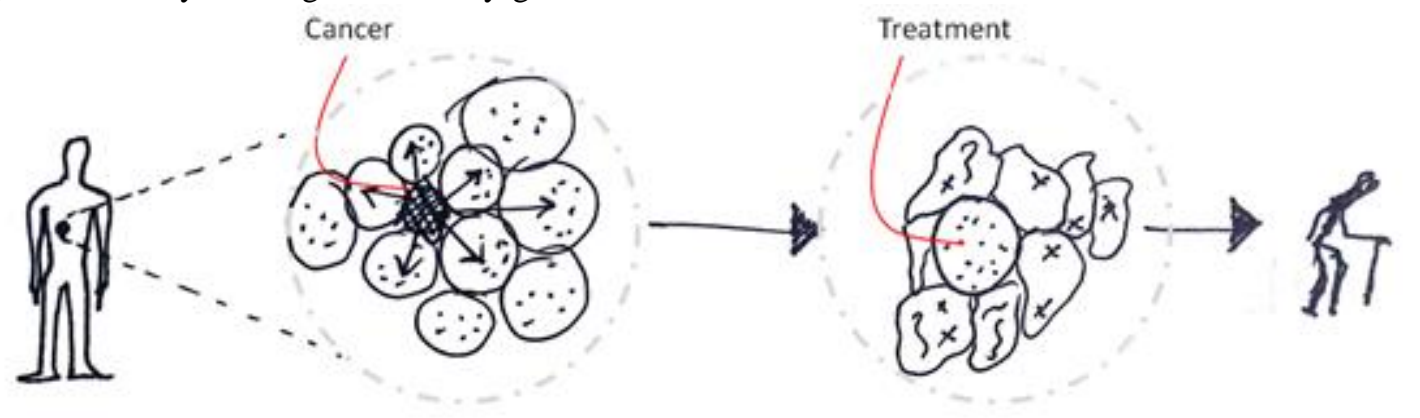

effect to the whole body.

\section{Cancer cell growing to other body parts \\ Only treating cancer can damage other parts of the body}

Fig 7. Side effects for giving treatment to solely a body part

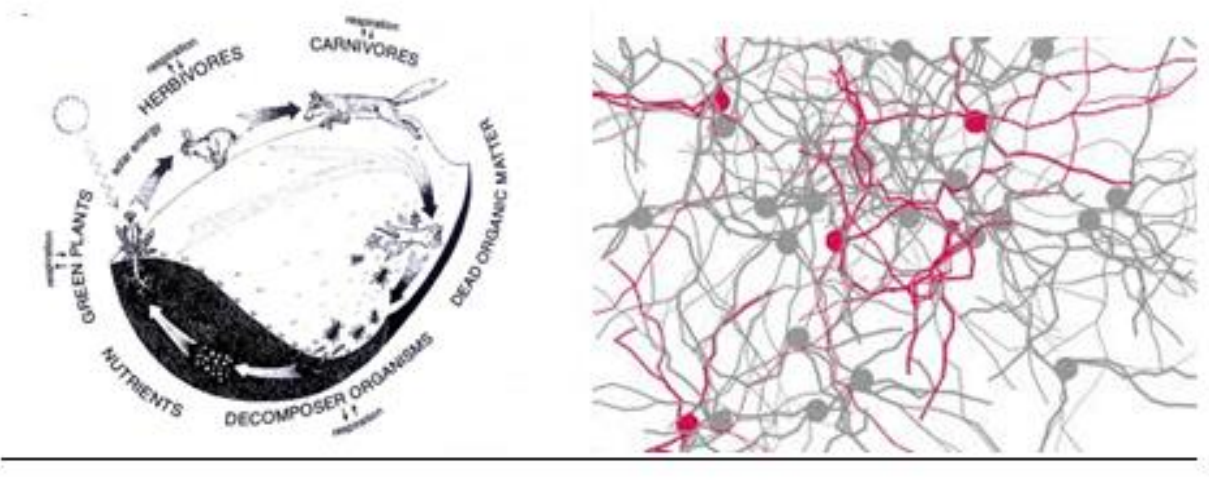

Fig 8. The web of a city system can be comparable to a living organism

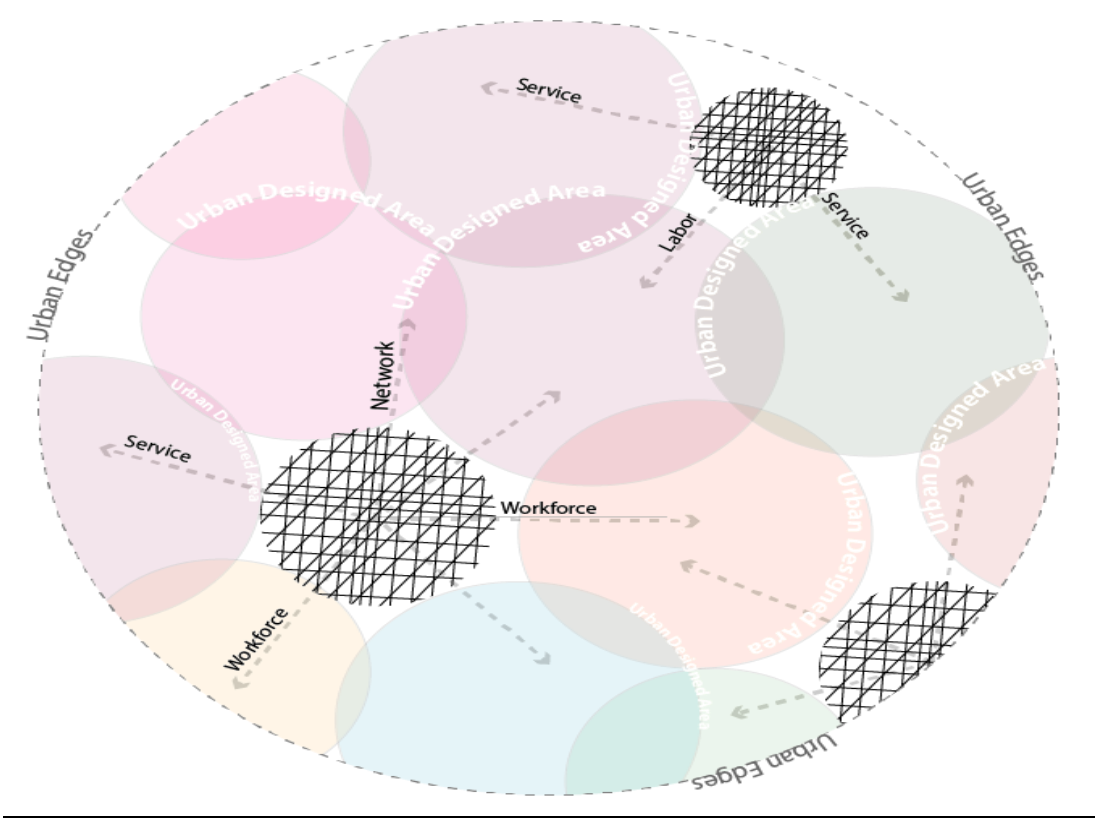

Fig 9. The web of a city system (an illustration made by the author); the crossed dark places are the slums, where urban design did not happen, but these dark circles actually running the city mechanism and efficiency of the total urban designed area. 
Today rather than curing disease healing the disease by dealing it with the whole body immune system is getting more popular for its permanent cure for the disease. The sustainability of the medicine depends on if the disease is coming back or not. Such like that, if we upgrade a slum, the sustainability depends on how long the slum remains upgraded. As deterioration of the living area and life style even after upgrading is a common phenomenon in a slum, because of poverty and scarcity. So at first we need to address the problem of poverty of the people of slums to make them economically and socially uplifted. We need to cure their soul from their belief of 'negligence' and develop their self-esteem by providing quality education and integrating them with rest of the people of the society. So that they feel secured, respected and thus want to uplift their living pattern in a sustainable manner.

\subsection{Understanding of Self-organization system for a better city}

Slums are actually the results of the complex systems in the web of the city. In complex systems we do not always know what the outcomes of interventions are. They are non-linear and not predictable using the traditional tools of science. In other words, slum is the result of inter-connectedness and inter-dependency of urban rich with urban poor in a city.

If a system shows an organization of physical elements, we tend to assume that someone or something must have designed it in that particular order. Self-organization is the idea that this type of global coordination can instead be the product of local interactions [13]. Similarly slums are the product of self-organization system of the city. When there is an external intervention, a system of self-organization can often get scattered and reform another cluster into another place, just like the birds' flake in the sky, if there is any obstacle, the birds get scattered, and reform the cluster again in another place if we compare slum with this phenomenon, we can see that slums actually have the character of selforganization rather than rules and regulation. In this kind of systems, rather than giving a program based intervention, it is very important to make a change by a giving a 'push planning' so that the system changes automatically in a spontaneous way.

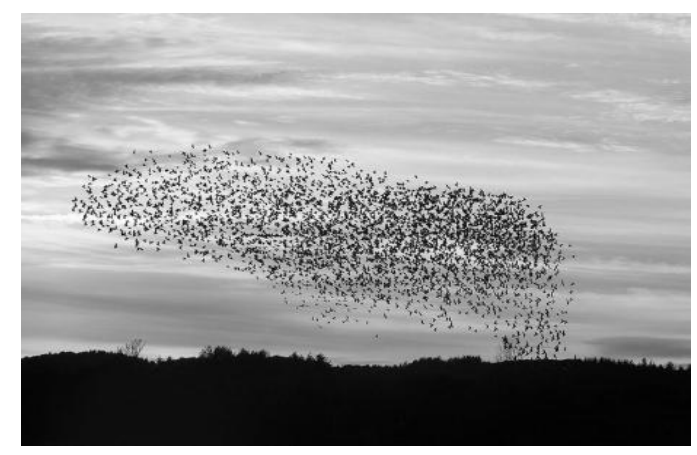

Fig 10. Birds flocking, an example of self-organization in biology; source: Christoffer A Rasmussen
Juval Portugali (1999) states that an unplannable area should be handled by pushing the elements of a self-organized system [11]. Portugali suggests that planning should be 'just-in-time rather than 'just-in-case'.

Accordingly, we should find out the push factors of the slum, and stimulate it to achieve the 'just-in-time' situation, before we proceed for the top-down program approach to upgrade it.

\section{SUMMARY \& CONCLUSION}

In this world of globalization today, physical change of a city is a matter of time only. But the 'push factor' for a physical change of a society is definitely its economy and education status. The same way we can say it for a slum, where physical improvement is impossible if there is no 'push factor' working behind it. For architecture and urban design, we always prefer to study the cases or examples from around the world. But if anybody wants to study the cases of slums around the world, will definitely get disappointed finding out no similarities among them. Dividing the slums according to living status, based on economy and education, was the simplest way I could figure out the human characteristics of the slum dwellers and their relationship with the physical components of the slums.

Complex system theories has proven that individual elements have its own properties and it is only can be understood when it is studied with its surrounding networks. Thus, a living place of urban poor, which we call 'slum' today, can only be understood when we learn about the character and behavior of its network, which is the city, and get familiar with it for years. Study of urbanism has already gone beyond thinking merely about physical things and incorporated understanding of intangible elements of the urbanism such as selforganization systems or human resilience response for generation or regeneration of cities. Physical changes can of course make social changes, although it is ambiguous and sometimes unpredictable, but it is obvious that the intangible elements are mostly responsible for the sustainability of tangible or physical elements of urban life. When the physical things do not work, it is better to start with the intangible elements to start an urban design or planning project. The core message of this paper was to introduce this fact to the urban designers or policy makers who are working for the slum upgrading issues in poverty surrounded developing cities for decades but could not find the answer except creating new questions.

\section{ACKNOWLEDGEMENTS}

This paper had been conducted to as a part of the study of my Master thesis of MUD program in the University of Hong Kong under the supervision of Prof. Chu, Paul Hoi Shan, DUPAD, HKU. I gratefully thank him for his consistent support and suggestions. The final outcome of this study helped to generate a hypothesis for my master thesis by examining different slums in different places in the world. 


\section{REFERENCES}

[1] Acioly, C. (2014). Street Led Citywide Slum Upgrading. https://www.youtube.com/watch?v=k12XNVzCUvY. UK.

[2] Angel, S., \& Benjamin, S. (1976). Seventeen Reasons why the Squatter Problem cannot be Solved. In Ekistics 242 (pp. 20-26).

[3] Birch, E. L. (2014, April 22). UN-Habitat Global Urban Lectures: Slums and Cities: Past, Present and Future. Retrieved June 2014, from https://www.youtube.com/watch?v=pFD7hPJ37Iw\&list=PLTQZb Ec6Bv5-Hja_AppdM6gkXp98C01Ca

[4] Capra, F. (1996). THe Web of Life. New York: Doubleday.

[5] CODI. (2011). Baan Mankong Collective Housing. Retrieved July 2014 from http://www.codi.or.th/housing/aboutBaanmankong.html

[6] CODI. (2005). Baan Mankong: An update on CITY-WIDE UPGRADING in Thailand. A publication of the Community Organizations Development Institute (CODI) , 2-13.

[7] Emam, A. (2009). EGYPT: Out of the slum and into joblessness. Cairo, Egypt: IRIN News.

[8] Huque, A. (1982). The Myth of Self-Help Housing (1982 ed.). Stockholm: Williamsssons Offsetryck AB.

[9] Marx, B., stoker, T., \& Suri, T. (Fall 2013). The Economics of Slum in the Developing World. Journal of Economic Perspectives-Volume 27, Number 4, 187-210.

[10] epitUNHabitat (Producer). (21 December, 2012). Parcipatory Slum Upgrading Program Overview [Motion Picture]. https://www.youtube.com/watch?v=rrdbGfQR7N8.
[11] Portugali, J. (1999). Self-Organization and the city. Tel-Aviv: Springer.

[12] Rodell, R. J. (1983). People, Poverty and Shelter: Problems of Sel-help Housing in the third world. New York: Methuen \& Co.

[13] Systems Innovation. (2014). Self-Organization Overview. https://www.youtube.com/watch?v=BTR17I_Eb_o.

[14] Taher, M. T., \& Ibrahim, A. (2014). Transformation of Slum and Squatter Settlements: A Way of Sustainable Living in Context of 21 st Century Cities. American Journal of Civil Engineering and Architecture, Vol. 2, No. 2, 70-76.

[15] Turkstra, J., \& Sietchiping, R. (2012). Sustaining Urban Land Information. Nairobi: UN Habitat.

[16] Turner, J. F., \& Fitcher, R. (1972). Freedom to Build: Dweller Control of the Housing Process. (R. F. John F.C. Turner, Ed.) Macmillan.

[17] UNDP. (2006). UN Millenium Project 2002-2006. Retrieved June 2014, from http://www.unmillenniumproject.org/goals/gti.htm

[18] UN-Habitat. (2014). Participatory Slum Upgrading Programme (PSUP). Retrieved June 2014, from http://unhabitat.org/initiativesprogrammes/participatory-slum-upgrading/

[19] USDA. (2014). USDA Rural Development. USDA.gov. Retrieved from http://www.rurdev.usda.gov/rhs/sfh/brief_selfhelpsite.htm

[20] Werlin, H. (1999). The Slum Upgrading Myth. In Urban Studies, Vol.36 (Vol. 36, pp. 1523-1534). SAGE.

[21] Wikipedia. (2020, February 25). Retrieved from Wikipedia: https://en.wikipedia.org/wiki/Shanty_town 